\title{
Influence of Mineral Fertilizers and Other Agrotechnical Cultivation Methods on Yield and Grain Protein Content of Winter Wheat
}

\author{
Gasanova Iryna, Yerashova Marharyta, Astakhova Yanina*, Drumova Olena \\ Laboratory of Agrobiological Resources of Winter Grain Crops, State Establishment Institute of Grain Crops of the National Academy of \\ Agrarian Sciences of Ukraine, Dnipro, Ukraine
}

Email address:

yana123.astax@gmail.com (A. Yanina)

*Corresponding author

\section{To cite this article:}

Gasanova Iryna, Yerashova Marharyta, Astakhova Yanina, Drumova Olena. Influence of Mineral Fertilizers and Other Agrotechnical Cultivation Methods on Yield and Grain Protein Content of Winter Wheat. American Journal of Agriculture and Forestry.

Vol. 9, No. 2, 2021, pp. 89-94. doi: 10.11648/j.ajaf.20210902.17

Received: March 19, 2021; Accepted: April 1, 2021; Published: April 12, 2021

\begin{abstract}
It is established that in the conditions of the northern steppe of Ukraine to obtain comparable results in the amount of protein in winter wheat grain it is necessary after such predecessors as stubble and sunflower, to apply a higher dose of nitrogen in complete pre-sowing fertilizer, as well as in spring fertilization, than when growing on black fallow. In the case of fertilization at the end of plants tillering with nitrogen with a local dose of $\mathrm{N}_{60}$, the yield after spring barley, depending on the variety of winter wheat increased by $0.66-0.82$, and for black fallow - by $0.58-0.64 \mathrm{t} / \mathrm{ha}$. Among winter wheat varieties Kokhanka, Misia Odeska and Pylypivka, the highest yields and grain quality were observed in Pylypivka variety. It was found that among nitrogen fertilizers (ammonium nitrate, Urea Ammonium Nitrate solution - UAN-32, and ammonium sulfate) the best results in protein formation in grain in most cases provided the introduction of UAN-32 and ammonium sulfate. Strong in grain quality, winter wheat varieties Niva Odeska and Uzhynok, both after sunflower and black fallow, outperformed Kokhanka variety in terms of protein content. It is established that the highest grain productivity of different varieties of winter wheat, both when grown after spring barley and black fallow, was observed at the optimal sowing date (September 22); the variety of durum wheat Burshtyn formed a higher protein content in the grain (13.5-14.6\%) than varieties of soft wheat Golubka Odeska (12.0-12.6\%) and Lastivka Odeska 13.2-13.6\%). It was found that in the research years the amount of protein in the grain of winter wheat depended more on crop fertilizer than on the sowing date.
\end{abstract}

Keywords: Winter Wheat, Variety, Predecessor, Mineral Fertilizers, Nitrogen Fertilization, Sowing Date, Yield, Grain Protein Content

\section{Introduction}

Winter wheat (Triticum aestivum L.) is one of the most valuable food crops in the world. In recent years, Ukraine, where winter wheat is grown annually on area of 6-7 million hectares, has entered the top ten producer countries and has become one of the world's leading grain exporters of this crop [1]. Among the nature-climatic zones of Ukraine (Forest Lowland, Forest-Steppe, Steppe), the steppe zone has the most favorable conditions for the formation of wheat grain with improved quality [2-4]. But in general, the yield and grain quality of winter wheat depend on the complex action of environmental, agronomic and biological factors [5-8].

The concept of grain quality should be understood as a set of properties and characteristics that determine its suitability for use with intended purpose. Mass fraction of protein is one of the main indicators as it is related to grain commodity value, flour milling, baking, as well as technological properties. The scientific research results and agricultural production practice show that over the past $80-90$ years in Ukraine's southern regions the protein content of winter wheat grain has decreased from $17-18$ to $10-12 \%$, and in adverse weather conditions the amount of grain protein may decrease even to $8.0-9.5 \%[4,9]$. This is largely due to the 
introduction of intensive cultivation technologies, use of new generation varieties capable of forming high yield level. Therefore, nowadays it is important to focus research on overcoming the inverse relationship "crop-protein" regardless of weather-climatic conditions by improving the agronomic methods of growing wheat.

Among the modern varieties of winter wheat, the most widespread in Ukraine are soft varieties, their grain is most suitable for the needs of flour-milling and baking industry. At the same time, introduction of durum wheat varieties into production deserves special attention, as they better suite the production of high-quality cereals and pasta.

It is known that in recent years in the steppe zone winter wheat crops are expanding after non-traditional predecessors: sunflower, stubble ears, rapeseed, grain sorghum, which have a negative impact on moisture, soil nutrition. Growing stable yields of high quality food grain after such predecessors is one of the important tasks now [10-12]. The sowing dates also have a great influence on the yield and grain quality of winter wheat; they are vital for plants growth and development, survival, frost and winter hardiness, density of productive stems, and others charachteristics $[5,13]$.

It has been proved that ear grains, and especially winter wheat, are crops with an increased need for mineral nutrition. And one of the most important technology methods for growing high grain yields with improved grain quality is the optimization of plants nitrogen nutrition during growing season. Nitrogen fertilizers are of great importance not only in plant nutrition, they act as activators in processes of soil nitrogen and other necessary elements mobilization. The question of different doses and nitrogen yields dates in cultivation of winter wheat has been studied by a number of researchers [14-17]. Nevertheless, there is no consensus on the best application modes for these fertilizers.

In recent years, both in Ukraine and in other countries, the use of liquid nitrogen fertilizers has become more widespread in the cultivation of many crops, as they have a number of advantages over solid ones. Among such fertilizers, one of the leading places is occupied by Urea Ammonium Nitrate mixture (UAN) - a solution of ammonium nitrate and urea in a ratio of $1: 1$, which contains $28-32 \%$ of nitrogen. The cost of this fertilizer is lower than solid nitrogen fertilizers, UAN does not contain free ammonia, which makes it possible to apply it on the surface of the soil. At the same time high accuracy of dosing and uniformity of placement on a soil surface is reached. In the process of UAN production, microelements and plant protection products can be introduced into its composition. According to recent years research, in terms of physiology and agrochemistry of plant nutrition, UAN is one of the best nitrogen fertilizers for ear grain crops [18].

Effectiveness comparison for different types of nitrogen fertilizers used in the feeding of winter wheat plants during the growing season is a promising area of research today.

At a time when there are significant climate changes, new high-yielding varieties are being introduced into production, scientific research conducted in the steppe zone is relevant and undoubtedly important for both science and production.

\section{Materials and Methods}

Field experiments were fulfilled at the State Enterprise "Experimental Farm Dnipro" at the State Establishment "Institute of Grain Crops of NAAS" in accordance with the generally accepted methods of field experiment [19]. Predecessors of winter wheat are - black fallow $\left(\mathrm{N}_{30} \mathrm{P}_{60} \mathrm{~K}_{30}\right.$ was applied for pre-sowing cultivation), spring barley (mineral nutrition background, $\mathrm{N}_{60} \mathrm{P}_{60} \mathrm{~K}_{30}$, respectively) and sunflower $\left(\mathrm{N}_{60} \mathrm{P}_{60} \mathrm{~K}_{60}\right)$. The soil of the experimental plots is ordinary low-humus full-profile chernozem. The mechanical composition of the soil is medium loam. The average humus content in the arable soil layer is $3.2 \%$, the $\mathrm{pH}$ of the salt extract is close to neutral - 6.8-7.0. The content of mobile forms of phosphorus and potassium (according to Chirikov) is respectively $90-120$ and $70-120 \mathrm{mg} / \mathrm{kg}$ of absolutely dry soil, total nitrogen $-0.18-0.20 \%$. Nitrification capacity of chernozems arable layer on the farm is $17-20 \mathrm{mg} / \mathrm{kg}$ of absolutely dry soil. The climate of the zone is temperatecontinental with insufficient and unstable humidity.

The following varieties of soft winter wheat (variety Erythrospermum) were studied in various experiments: Kokhanka, Misia Odeska, Pylypivka, Golubka Odeska, Lastivka Odeska, Niva Odeska and Uzhynok, as well as durum wheat Burshtyn (variety Lutescens). Varieties Misia Odeska, Pylypivka, Lastivka Odeska, Golubka Odeska, Niva Odeska and Uzhynok belong to the group of strong in quality grains, and Kokhanka varietiy is a valuable one. Nitrogen fertilizers ammonium nitrate (containing 34.4\% nitrogen), urea ammonium nitrate mixture (UAN-32 - 32\% nitrogen), ammonium sulfate $(21.5 \%$ nitrogen $)$ were used for nitrogen fertilization of crops. The solution of UAN-32 during feeding was applied using a knapsack sprayer, adjusting the largedroplet spraying of the liquid.

Winter wheat was sown in a continuous row method with a $\mathrm{CH}-16$ seeder, the sowing rate was 5.0 million viable seeds / ha, the depth of wrapping was $5-6 \mathrm{~cm}$. The area of the elementary accounting plot was $30-35 \mathrm{~m}^{2}$, repeated 3 times. Winter wheat was harvested by a Sampo-500 combine harvester.

The protein content of winter wheat grain from different variants of experiments was determined on the NEOTEC device by infrared spectroscopy (for calibration of the device we used the values of total nitrogen obtained by the chemical method according to Kjeldahl - standard GOST 10846-91).

\section{Results and Discussions}

The mineral fertilizers are one of the most effective and fast-acting factors in increasing the winter wheat yield and improving its grain quality. At fertilization, the providing of this culture with nitrogen in the spring vegetation period especially its easily accessible forms has special value. At the same time, in order to obtain the best final results, nitrogen fertilization should be used against the background of pre- 
sowing application of complete mineral fertilizer (NPK). This is especially regard when winter wheat is grown after non-fallow predecessors [12, 21]. The high efficiency of nitrogen fertilization for winter wheat after sunflower proved with studies which were conducted earlier at the SE Institute of Grain Crop of NAAS. Thus, the nitrogen application of 30 $\mathrm{kg} / \mathrm{ha}$ in the form of ammonium nitrate (against the background of $\mathrm{N}_{90} \mathrm{P}_{60} \mathrm{~K}_{60}$ ) in the spring on frozen-thawed soil increased the grain yield compared with the without fertilizers variant by $0.61 \mathrm{t} / \mathrm{ha}$, and in the shooting stage - by $0,69 \mathrm{t} / \mathrm{ha}$. The increase in yield with double fertilization of crops $\left(\mathrm{N}_{30}\right.$ on frozen-thawed soil and $\mathrm{N}_{30}$ in the shooting stage) was $0.89 \mathrm{t} / \mathrm{ha}$. The protein content in the grain from $9.52 \%$ in the control variant (without fertilizers) increased to
9.86-12.86\% depending on the doses and term of mineral fertilizers [22].

In recent years in the experiment that compared winter wheat varieties Kokhanka, Misia Odeska and Pylypivka reaction to feeding with nitrogen fertilizer ammonium nitrate at the end of tillering stage locally, it was found that such feeding primarily also affects crop yields. In general, after black fallow (background $\mathrm{N}_{30} \mathrm{P}_{60} \mathrm{~K}_{30}$ ) all winter wheat varieties formed a higher yield than after spring barley (background $\mathrm{N}_{60} \mathrm{P}_{60} \mathrm{~K}_{30}$ ). Depending on the experiment variant, on average for 2016-2018, after fallow the yield varied in the range of 6.30-7.23 t/ha, after the non-fallow predecessor - in the range of 3.88-5.25 $\mathrm{t} / \mathrm{ha}$ with the highest rates after both predecessors for Pylypivka variety (Table 1).

Table 1. Impact of nitrogen feeding on yield and grain protein content for different varieties of soft winter wheat, 2016-2018.

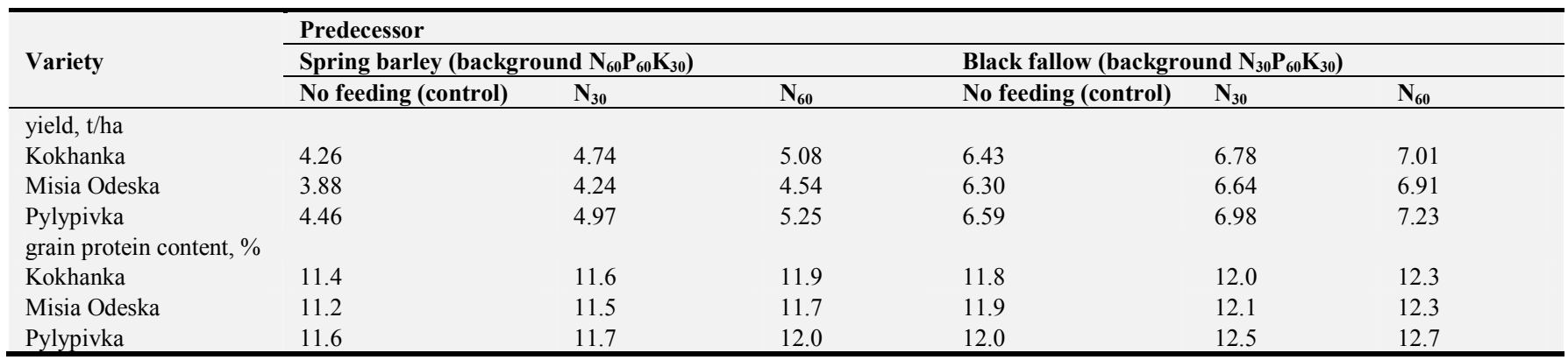

The yield level after spring barley with $\mathrm{N}_{30}$ feeding increased, compared to control group (without feeding), depending on variety by $0.36-0.51 \mathrm{t} / \mathrm{ha}, \mathrm{N}_{60}$ application provided an increase in grain yield $0.66-0.82 \mathrm{t} / \mathrm{ha}$ with the highest rates in varieties Kokhanka and Pylypivka. For black fallow, similar feedings contributed to yield increase depending on nitrogen fertilizer doses by $0.34-0.39$ and 0.58 $0.64 \mathrm{t} / \mathrm{ha}$.

The winter wheat grain protein content with application of a $\mathrm{N}_{30}$ nitrogen fertilizer dose relatively to control group increased insufficiently (after spring barley by $0.1-0.3 \%$, after black fallow - by $0.2-0.5 \%$ ). Use of $\mathrm{N}_{60}$ dose provided an increase in protein relative to control by $0.4-0.5 \%$ after stubble precursor and by $0.4-0.7 \%$ after black fallow.

The aim of other research conducted in 2017-2019 was to identify the impact of different types of nitrogen fertilizers applied during the soft winter wheat growing season on yield and grain quality after sunflower and black steam. The following types of nitrogen fertilizers were used for the experiment: ammonium nitrate, UAN-32, ammonium sulfate. Feeding with nitrogen fertilizers was performed according to the experiment schedule.

Nitrogen feedings had a positive effect on yield grain quality formation. After both predecessors, the best results were obtained in cases where crops were fed twice with each fertilizer type: $\mathrm{N}_{30}$ in early spring on permafrost and $\mathrm{N}_{30}$ at the end of the tillering stage locally; thus with a total spring nitrogen dose of $60 \mathrm{~kg} / \mathrm{ha}$.

According to three-year data, the average yield by varieties in the control variant (without feeding) when growing winter wheat after sunflower was $3.62 \mathrm{t} / \mathrm{ha}$, for black fallow it was higher by $2.03 \mathrm{t} / \mathrm{ha}$ and reached $5.65 \mathrm{t} / \mathrm{ha}$. Application of nitrogen feeding $\mathrm{N}_{30}$ on frozen-thawed soil and $\mathrm{N}_{30}$ at the end of plants tillering contributed to an increase in yield; compared to control, depending on the type of nitrogen fertilizer by $0.53-0.74 \mathrm{t} / \mathrm{ha}$ after sunflower and by $0.66-0.82$ $\mathrm{t} /$ ha - after black fallow. It was found that the largest increase in grain yield in relation to control group was provided by nitrogen feeding of crops (in one or two steps) with UAN-32 fertilizer after both predecessors.

In variety Kokhanka that belongs to the group of valuable varieties for grain quality, the protein content in control variant (without fertilization) when grown after sunflower was $10.5 \%$, for black fallow - $11.1 \%$. The protein increase after sunflower with a single application of nitrogen fertilizers $\left(\mathrm{N}_{30}\right.$ on frozen-thawed soil) was, depending on fertilizer form, $0.9-1.1 \%$, after fallow - $0.3-0.7 \%$; for double application $\left(\mathrm{N}_{30}\right.$ on frozen-thawed soil $+\mathrm{N}_{30}$ locally) respectively to predecessor $1.4-1.6$ and $0.8-1.3 \%$ (Table 2).

In strong winter wheat varieties Niva Odeska and Uzhynok grain quality indicators were higher than in Kokhanka variety; similarly there was a greater efficiency of nitrogen fertilizer application in two doses. After non-fallow predecessor winter wheat Niva Odeska grain protein content with nitrogen fertilizers application in two doses varied, depending on fertilizer type, from 12.8 to $13.2 \%$; for black fallow - from 13.3 to $13.6 \%$. For Uzhinok variaty this indicator value for similar fertilizer after sunflower varied in the range of 12.5 $12.8 \%$, after fallow - in the range of $13.1-13.6 \%$ (in control group protein content respective to variety after non-fallow predecessor was 10.6 and $10.9 \%$, and after black fallow 12.1 and $12.2 \%$ ). 
More pronounced differences in different types of nitrogen fertilizers impact on winter wheat grain protein content formation were noted during its cultivation after black fallow. The best results, as a rule, were obtained in case of nitrogen fertilizers UAN-32 and ammonium sulfate application for feeding crops of all winter wheat varieties.

In winter wheat growing agricultural techniques sowing date is important. According to some scientists, early sowing leads to a decrease in grain protein content. Conversely, the value of this indicator increases with winter wheat sowing at a later date, when plants form smaller vegetative mass and are better supplied with soil nitrogen [2, 10, 20]. Nowadays new intensive varieties are introduced into production; in the conditions of significant climate changes these varieties are able to form stable yields even at admissibly late sowing dates. Therefore, there are changes in the existing ideas about the role of some winter wheat cultivation agrotechnical methods in yield formation and grain quality.

According to research conducted with different varieties of winter wheat sown on September 7; September 22 and October 7, it was found that in the conditions of 2017-2019 after black fallow (on the background of $\mathrm{N}_{30} \mathrm{P}_{60} \mathrm{~K}_{30}$ ) the yield of variety Lastivka Odeska varied depending on the sowing date from 6.11 to $7.39 \mathrm{t} / \mathrm{ha}$, variety Golubka Odeska - from 6.81 to $7.07 \mathrm{t} / \mathrm{ha}$, and variety Burshtyn - from 5,18 to 6.11 $\mathrm{t} / \mathrm{ha}$.

Table 2. Grain protein content in soft winter wheat depending on feedings with different types of nitrogen fertilizers, \%, 2017-2019.

\begin{tabular}{|c|c|c|c|c|c|c|}
\hline \multirow{4}{*}{ Nitrogen fertilizer } & \multicolumn{6}{|l|}{ Predecessor } \\
\hline & \multicolumn{3}{|c|}{ Sunflower (background $\mathrm{N}_{60} \mathrm{P}_{60} \mathrm{~K}_{60}$ ) } & \multicolumn{3}{|c|}{ Black fallow (background $\mathrm{N}_{60} \mathrm{P}_{60} \mathrm{~K}_{30}$ ) } \\
\hline & \multicolumn{6}{|l|}{ Variety } \\
\hline & Kokhanka & Niva Odeska & Uzhynok & Kokhanka & Niva Odeska & Uzhynok \\
\hline Background (control) & 10.5 & 10.6 & 10.9 & 11.1 & 12.1 & 12.2 \\
\hline $\begin{array}{l}\text { Background }+\mathrm{N}_{30} \text { in early spring on frozen-thawed soil, } \\
\text { ammonium nitrate }\end{array}$ & 11.6 & 12.3 & 12.1 & 11.4 & 12.7 & 12.5 \\
\hline $\begin{array}{l}\text { Background }+\mathrm{N}_{30} \text { in early spring on frozen-thawed soil, } \\
\text { UAN-32 }\end{array}$ & 11.5 & 12.1 & 12.0 & 11.8 & 12.9 & 12.7 \\
\hline $\begin{array}{l}\text { Background }+\mathrm{N}_{30} \text { in early spring on frozen-thawed soil, } \\
\text { ammonium sulfate }\end{array}$ & 11.4 & 12.1 & 12.2 & 11.5 & 13.0 & 12.9 \\
\hline $\begin{array}{l}\text { Background }+\mathrm{N}_{30} \text { in early spring on frozen-thawed soil } \\
+\mathrm{N}_{30} \text { at the end of plants tillering, ammonium nitrate }\end{array}$ & 11.9 & 12.8 & 12.5 & 11.9 & 13.3 & 13.1 \\
\hline $\begin{array}{l}\text { Background }+\mathrm{N}_{30} \text { in early spring on frozen-thawed soil } \\
+\mathrm{N}_{30} \text { at the end of plants tillering, UAN-32 }\end{array}$ & 12.0 & 13.2 & 12.7 & 12.3 & 13.3 & 13.3 \\
\hline $\begin{array}{l}\text { Background }+\mathrm{N}_{30} \text { in early spring on frozen-thawed soil } \\
+\mathrm{N}_{30} \text { at the end of plants tillering, ammonium sulfate }\end{array}$ & 12.1 & 12.8 & 12.8 & 12.4 & 13.6 & 13.6 \\
\hline
\end{tabular}

After spring barley (on the background of $\mathrm{N}_{60} \mathrm{P}_{60} \mathrm{~K}_{30}$ ) fewer productive stems per unit area were formed than after black fallow, and the average yield was lower during the three years of research, despite the fact that after non-fallow predecessor a bigger dose of nitrogen in the complex fertilizer was used before sowing. Thus, in variety Lastivka Odeska grain yield depending on sowing date varied in the range of 4.31-5.04 t/ha, in variety Golubka Odeska - 5.48$6.01 \mathrm{t} / \mathrm{ha}$, and in variety Burshtyn - 4.29-5.02 t/ha, and the maximum grain productivity was observed for sowing in the optimal date.

The grain protein formation after spring barley did not depend on the sowing date; black fallow in most cases showed a tendency to increase the amount of grain protein at the optimal sowing date (September 22). Among the varieties of soft wheat (Golubka Odeska and Lastivka Odeska) the highest grain protein content after both predecessors was noted in the variety Lastivka Odeska. After comparison of all three studied varieties we found more grain protein in durum wheat grain (Burshtyn), than in soft varieties (Table 3).

Table 3. Impact of sowing date and crop fertilizer on grain protein content in different varieties of winter wheat, \%, 2017-2019.

\begin{tabular}{|c|c|c|c|c|c|c|c|}
\hline \multirow{4}{*}{ Variety } & \multirow{4}{*}{ Sowing date } & \multicolumn{6}{|c|}{ Predecessor } \\
\hline & & Spri & & & Blacl & & \\
\hline & & \multicolumn{6}{|c|}{ Fertilizer } \\
\hline & & $1^{*}$ & $2^{* * *}$ & $3^{* * *}$ & 1 & 2 & 3 \\
\hline \multirow{3}{*}{ Golubka Odeska (soft wheat) } & September 7 & 10.9 & 11.4 & 12.4 & 11.0 & 11.6 & 12.2 \\
\hline & September 22 & 10.9 & 11.3 & 12.1 & 11.2 & 11.8 & 12.6 \\
\hline & October 7 & 10.7 & 11.1 & 12.0 & 11.1 & 11.5 & 12.1 \\
\hline \multirow{3}{*}{ Lastivka Odeska (soft wheat) } & September 7 & 11.5 & 12.5 & 13.4 & 12.0 & 12.4 & 13.3 \\
\hline & September 22 & 11.8 & 12.8 & 13.2 & 12.7 & 13.1 & 13.6 \\
\hline & October 7 & 11.5 & 12.0 & 13.3 & 12.4 & 12.6 & 13.3 \\
\hline \multirow{3}{*}{ Burshtyn (durum wheat) } & September 7 & 12.5 & 12.7 & 14.4 & 12.9 & 13.3 & 14.6 \\
\hline & September 22 & 12.2 & 12.6 & 13.5 & 13.4 & 13.7 & 14.5 \\
\hline & October 7 & 11.9 & 12.8 & 14.5 & 13.4 & 13.6 & 14.3 \\
\hline
\end{tabular}

Notes: * Without fertilizers (control); ** Pre-sowing application of fertilizers: after spring barley $-\mathrm{N}_{60} \mathrm{P}_{60} \mathrm{~K}_{30}$, for black fallow $-\mathrm{N}_{30} \mathrm{P}_{60} \mathrm{~K}_{30}$; *** On the background of pre-sowing fertilizer after spring barley, $\mathrm{N}_{30}$ was applied on frozen-thawed soil $+\mathrm{N}_{30}$ at the end of plants tillering locally, on black fallow - $\mathrm{N}_{30}$ locally. Ammonium nitrate was used for nitrogen feeding. 
Thus, in variety Golubka Odeska after spring barley depending on the sowing date and fertilizer the amount of grain protein varied within $10.7-12.4 \%$, in variety Lastivka Odeska - 11.5-13.4\%, and in durum wheat Burshtyn - 11.9$14.5 \%$. When growing winter wheat on black fallow, the values of grain protein indicator according to respective variety were $11.0-12.6 \% ; 12.0-13.6$ and $12.9-14.6 \%$.

Application of complete mineral fertilizer with pre-sowing cultivation, as well as nitrogen feeding in spring vegetation of winter wheat plants on the background of pre-sowing fertilization, contributed to the increase of protein content in winter wheat grain both after stubble predecessor and black fallow.

In the variety Golubka Odeska after spring barley, on the background of pre-sowing fertilizer $\mathrm{N}_{60} \mathrm{P}_{60} \mathrm{~K}_{30}$, with $\mathrm{N}_{30}$ feeding on frozen-thawed soil $+\mathrm{N}_{30}$ at the end of the tillering stage locally, grain protein content compared to options without fertilizers, increased depending on the sowing date by $1.2-1.5 \%$; in the variety Lastivka Odeska - by $1.4-1.9 \%$, Burshtyn - by $1.3-2.6 \%$. When growing winter wheat on black fallow, with the introduction of $\mathrm{N}_{30}$ at the end of tillering stage locally on the background of $\mathrm{N}_{30} \mathrm{P}_{60} \mathrm{~K}_{30}$, the grain protein content compared to control group increased respectively by $1.2-2.0 \% ; 0.9-1.3$ and $0.9-1.7 \%$. It was found that grain protein increase after stubble predecessor was bigger in varieties Lastivka Odeska and Burshtyn, and after black fallow - in variety Golubka Odeska.

On the background without mineral fertilizers, a significant advantage should be noted in wheat grain protein formation if grown after black fallow, compared to stubble predecessor. On other mineral nutrition backgrounds, this difference was usually eliminated due to the fact that after spring barley, according to the experiment shedule, more nitrogen was applied in complete fertilizer and feeding.

\section{Conclusions}

In conditions of Ukraine's northern steppe, for soft winter wheat varieties Kokhanka, Misia Odeska and Pylypivka when crop feeding with nitrogen fertilizer ammonium nitrate during tillering end locally, it was found that such fertilization primarily affects the crop yield. Based on threeyears research results with application of $\mathrm{N}_{60}$ dose, grain yield after spring barley increased, compared to control (without fertilization), depending on variety by $0.66-0.82 \mathrm{t} / \mathrm{ha}$; after black fallow - by $0.58-0.64$ t/ha. Depending on experiment variant, the yield after spring barley varied in the range of 3.88-5.25 t/ha, after fallow - in the range of 6.30$7.23 \mathrm{t} / \mathrm{ha}$ with the highest indicators after both predecessors in Pylypivka variety. $\mathrm{N}_{60}$ dose application provided an increase in protein compared to control after the stubble predecessor - by $0.4-0.5 \%$ and after black fallow - by $0.4-$ $0.7 \%$.

When for winter wheat crops feeding such fertilizers as ammonium nitrate, UAN-32 and ammonium sulfate were used the best indicators of yield and grain quality after sunflower and black fallow were obtained in cases where crops were fed twice with each type of nitrogen fertilizer: on frozen-thawed soil $\left(\mathrm{N}_{30}\right)$ and at tilling end locally $\left(\mathrm{N}_{30}\right)$. Thus the total dose of nitrogen application in spring growing season was $60 \mathrm{~kg} / \mathrm{ha}$. Winter wheat varieties with strong grain quality Niva Odeska and Uzhynok formed higher protein content than Kokhanka variety. After black fallow, where a more contrasting impact of nitrogen fertilizers was noticed on winter wheat grain protein formation, the best results were provided by application of UAN-32 and ammonium sulfate.

The highest grain productivity of different varieties of winter wheat, both when grown after spring barley and black fallow, was observed at the optimal sowing date (September $22)$. Winter wheat grain protein formation when grown after spring barley did not have a significant dependence on sowing date. After black fallow, cultivation showed a tendency to increase grain protein content with optimal sowing date. The maximum values of winter wheat grain protein after both predecessors were observed with use of crop fertilization system that included pre-sowing fertilization and spring nitrogen feedings. For variety Golubka Odeska (soft wheat) with such fertilization type depending on predecessor and sowing date grain protein content varied in the range of $12.0-12.6 \%$, for Lastivka Odeska (also soft wheat) - 13.2-13.6\%, for variety Burshtyn (durum wheat) - 13.5-14.6\%.

\section{References}

[1] Kernasyuk, Y. V. (2020). The global wheat market: conditions and trends. Agribusiness today, 22 (437), 12-16.

[2] Zhemela, G. P., Musatov, A. G. (1989). Agrotechnical bases for improving grain quality. K.: Urozhay, 160.

[3] Strelnikova, M. M. (1971). Improving the quality of wheat grain. Kyiv: Urozhay, 180.

[4] Nikolaev, E. V. (1991). Reserves for increasing grain production of strong and valuable wheat. K.: Urozhay, 232.

[5] Cherenkov, A. V. at al. (2015). Winter wheat in the steppe zone, climate change and cultivation technologies: monograph. Dnipropetrovsk: Nova Ideologiya, 548.

[6] Cherenkov, A. V., Nesterets, V. G., Solodushko, M. M., Krotinov, I. V. (2016). Agroecological and technological factors in the formation of winter wheat yield in the area of the south-eastern steppe of Ukraine. "Irrigated agriculture: interdepartmental compilation". Kherson: Grin DS, 66, 94101.

[7] Herman, M. M., Marenych, M. M. (2013). Grain quality of soft winter wheat and ways to improve it. Bulletin of Poltava State Agrarian Academy. Vip., 4, 19-22.

[8] Zhemela, G. P. (2005). Agroecological factors to improve the quality of winter wheat grain. Scientific works of Poltava State Agrarian Academy, II (23), 38-43. 
[9] Kramarov, S. M., Zhemela, G. P., Shakalij, S. M. (2014). Yield and grain quality of soft winter wheat depending on mineral fertilization in conditions of left bank forest-steppe zone of Ukraine. Byuleten Institutu Silskogo Gospodarstva Stepovoi Zoni NAAN Ukrainy, 6, 61-67.

[10] Netis, I. T. (2011). Winter wheat in the south of Ukraine. Monograph. Kherson: Oldi-plus, 460.

[11] Cherenkov, A. V., Gasanova, I. I., Kostyrya, I. V., Ostapenko, M. A., Bilozor, I. V. (2018). Impact of predecessors, mineral fertilizers and sowing methods on the yield and grain quality of winter wheat in the southern steppe of Ukraine. Scientific journal "Grain crops". Dnipro, 2 (2), 237-244. https://doi.org/10.31867/2523-4544/0031

[12] Usova, N. M, Solodushko, M. M., Romanenko, O. L. (2018). Influence of predecessors and mineral nutrition on yield and grain quality of winter wheat. Scientific journal "Grain crops". 2 (2), 281-286. https://doi.org/10.31867/2523-4544/0037

[13] Solodushko, M. M., Gasanova, I. I., Pryadko, Yu. M., Nosenko, Yu. M. (2016). Yield and quality of winter wheat and triticale grain depending on predecessors and sowing dates. Bulletin of the Institute of Steppe Zone Agriculture of NAAS of Ukraine. Dnipropetrovsk, 11, 35-39.

[14] Mineev, V. G., Pavlov, A. N. (1981). Agrotechnical bases for improving the quality of wheat grain. M.: Kolos, 289.

[15] Zhemela, G. P. (1991). Fertilizers, yield, and grain quality. K.: Urozhay, 136.
[16] Gospodarenko, G. M, Cherno, O. D, Boyko, V. P., Stasinevich, O. Y. (2018). Influence of doses and ratios of fertilizers on the yield and grain quality of winter wheat. Bulletin of Uman University of Horticulture, 2, 76-80. https://doi.org/10.31395/2310-0478-2018-21-76-79

[17] Maadi, B., Fathi, G., Siadat, S. A., Alami, S. K., Jafari, S. (2012). Effects of Preceding Crops and Nitrogen Rates on Grain Yield and Yield Components of Wheat (Triticum aestivum L.). World Applied Sciences Journal, 17 (10), 13311336.

[18] Kramaryov, S. (2018). Feeding plants with water solutions of CAS. Agrarian week Agrarnyj tyzhden, 6 (330), 52-55.

[19] Dospekhov, B. A. (1985). Methods of field experiments (with the basics of statistical processing of research results). M.: Agropromizdat, 352.

[20] Petrichenko, V. F., Likhochvor, V. V. (2014). Crop production. Technologies for growing agricultural crops. Lviv: Scientific and Production Enterprise "Ukrainian Technologies", 485.

[21] Tkachuk, K. S, Kuzmenko, L. M., Nizhko, V. F. (1991). Regulation of mineral nutrition and plant productivity (etc.). Kyiv, Naukova Dumka, 191.

[22] Sereda I. I. Agricultural Features of winter wheat growing after peas and sunflower in the conditions of Northern Steppes of Ukraine. Thesis for the candidate's degree by specialty 06.01.09. The Institute of Agriculture of Steppe zone of NAAS of Ukraine, Dnipropetrovsk, 2013. 